\title{
Karl Taro Greenfeld, China Syndrome. The True Story of the 21st Century's First Great Epidemic; Thomas Abraham, Twenty-First Plague. The Story of SARS.
}

Frédéric Keck

\section{OpenEdition}

Journals

Édition électronique

URL : http://journals.openedition.org/chinaperspectives/2763

DOI : 10.4000/chinaperspectives. 2763

ISSN : 1996-4617

Éditeur

Centre d'étude français sur la Chine contemporaine

Édition imprimée

Date de publication : 15 décembre 2007

ISSN : 2070-3449

\section{Référence électronique}

Frédéric Keck, « Karl Taro Greenfeld, China Syndrome. The True Story of the 21st Century's First Great Epidemic; Thomas Abraham, Twenty-First Plague. The Story of SARS. », China Perspectives [En ligne], 2007/4 | 2007, mis en ligne le 09 avril 2008, consulté le 23 septembre 2020. URL : http://

journals.openedition.org/chinaperspectives/2763; DOI : https://doi.org/10.4000/chinaperspectives. 2763

Ce document a été généré automatiquement le 23 septembre 2020.

(c) All rights reserved 


\title{
Karl Taro Greenfeld, China Syndrome. The True Story of the 21st Century's First Great Epidemic; Thomas Abraham, Twenty-First Plague. The Story of SARS.
}

\author{
Frédéric Keck
}

The SARS crisis in 2003 very quickly gave rise to a number of analyses on its consequences in terms of public health by setting China and the World Health Organisation (WHO) if in opposition to each other in a global and quite general way ${ }^{1}$. Few accounts, however, take into consideration the plurality of the actors who were involved in this crisis, the brevity of which (a few months between December 2002 and April 2003) disguises somewhat the intensity of the efforts to bring it to an end. Two accounts published by journalists, one by Thomas Abraham, assistant professor at the Journalism and Media Studies Centre of the University of Hong Kong, the other by Karl Taro Greenfeld, former director of Time Asia, retrace the evolution of the epidemic from a chronological and geographic perspective. The account by Thomas Abraham is more academic and retrospective, evaluating the succession of events from the point of view of the epidemiological results that were finally established. That of Karl Taro Greenfeld, though written at a later stage, presents the events "in the heat of the moment" and uses all the resources of journalistic suspense, re-creating the sense of uncertainty and urgency of the scientific data produced on the infectious agent. Both show that the fight against SARS not only brought China and the WHO into conflict, but also linked actors in diverse locations: Guangzhou , Hong Kong , and Beijing on the one hand, and Hanoi , Geneva , and Atlanta on the other. Greenfeld's book is a good introduction to the events that constituted the SARS crisis, as its novelistic style is lively and enjoyable to read. To claim that it is the "true story," as the subtitle makes out, is an exaggeration, however, for despite the efforts of the author to acquire and convey the foundations of virology, it is not lacking in scientific errors ${ }^{2}$. The book starts with a list 
of the dramatis personae, and indeed, its major interest lies in its recounting of the international comédie humaine grappling with the contagion. In his role as editor-inchief of Time Asia, Greenfeld had particularly good access to two types of actors: on the one hand, the two scientists at the University of Hong Kong who identified the cause of the disease, Malik Peiris and Guan Yi, and on the other, the Chinese doctors who, defying the official ban, revealed to the greater public the extent of the contagion: Zhong Nanshan, director of the Institute for Respiratory Diseases in Guangzhou , and Jiang Yanyong, a physician at the 301 Military Hospital in Beijing . It was Time Asia , in fact, that published in April 2003 the letter by Jiang Yanyong maintaining that the number of SARS victims was much higher than that declared by the Minister of Health, Zhang Wenkang, and it seems that this event was the trigger that pushed Greenfeld to undertake an investigation into the disease from the point of view of Hong Kong , where he was based at the time.

2 The narrative begins in November 2002, when the first victims of a mysterious respiratory disease were beginning to feel its symptoms in Guangzhou and Shenzhen. The author endeavours to follow an ordinary patient, Fang Lin, who refuses to admit himself to hospital for fear of the cost of medical care, and intermeshes his account with the inquiries conducted by Malik Peiris and Guan Yi on birds that had contracted avian flu in Hong Kong, comparing the contractions of the lungs of the human victims with the facial haemorrhages of the winged creatures in striking and bloody descriptions. We discover an essential factor in the crisis in the fact that the scientists who treated the first SARS victims in Hong Kong expected to encounter the H5N1 virus responsible for the avian flu that began afflicting Hong Kong in 1997: this crossover between the two infectious diseases initially caused a delay in the response of the Hong Kong health authorities to the SARS contagion, but then spurred a tremendous acceleration of research into the emerging viruses, which allowed the disease to be understood and may have controlled its spread. It was because Malik Peiris and Guan Yi had been working for 10 years on avian flu, under the supervision of Robert Webster, Kenneth Shortridge, and Kwok-Yung Yuen, that they were the first to show that SARS was caused by a coronavirus (21 April 2003) and that it had been transmitted to humans by civet cats sold in the markets of Guangzhou (23 May): the methods of reasoning and experimentation that had been tried and tested for the H5N1 virus were successfully applied to SARS. Greenfeld follows Malik Peiris and Guan Yi as they ask themselves about the identity of the virus, express scepticism or anger at the announcements of hypotheses by other scientists (the Chinese authorities talked of the Chlamydia bacteria, researchers at the Chinese University of Hong Kong of a metapneumovirus, the Center for Disease Control in Atlanta of a paramyxovirus), and cross the border to collect human and animal samples in Guangzhou or Shenzhen (thanks to the support of Zhong Nanshan). Despite its scientific errors, this account gives a good sense of the frantic competition between the different personalities and scientific institutions, accelerated by a feeling of urgency as people start dying of a disease that has yet to be identified.

3 The account broadens its horizons as SARS begins to spill over the Hong Kong/ Guangdong border to become a global pandemic. Greenfeld follows the doctor Liu Jianlun as he leaves Guangzhou, where he has been treating patients with the mysterious illness, and comes to Hong Kong to take part in a family celebration, only to die on 21 February. By then he had already infected a dozen or so people who had been 
staying, like him, at the Metropole Hotel, and who the next day took flights to Toronto , Hanoi , Singapore , and Beijing, where they spread the disease. Greenfeld follows one of them, Danny Yang Chin (Johnny Cheng), an American of Chinese origin, as he is treated in the French Hospital of Hanoi, where he infects several nurses as well as Dr. Carlo Urbani, who was the first to inform the WHO of the appearance of the first cases and who himself tragically died of SARS in Bangkok on 20 March 2003.

Rather than looking at the cases in Singapore, Toronto, and Taiwan that also resulted from this first infection ${ }^{3}$. Greenfeld once again narrows in on Hong Kong, where two phenomena dominate the story: the infection of nurses and doctors at the Prince of Wales Hospital, which traumatises the medical staff, and the infection of residents of the Amoy Gardens housing estate, which triggers panic in the general population and leads to wild hypotheses that the virus was transmitted by rats or crows or was simply airborne before epidemiologists ultimately trace the blame to ventilation ducts linked to the toilet drainage system. Greenfeld skilfully recreates the atmosphere of suspicion in Hong Kong , the flight of expatriates, and the complete shutdown of activity, extending to the editing desk of Time Asia.

In one of the most lyrical passages of the book - which also betrays the point of view of a person who, although born of a Japanese mother, remains attached to an American intellectual elite - the author, on the point of sending his wife and children on holiday to Sri Lanka , contemplates the city from his flat at the top of the Peak and imagines the virus passing from one district to another through the feverish bodies of their residents (p. 256). In a fascinating and recurring theme that serves as a sort of key to the book, the author plays at "Guan Yi's game consisting of pretending to be a virus" (p. 250): he pictures himself passing from body to body, seeking out the organisms that are most suitable for its reproduction. In fact, the interest of this book lies in "following the viruses" by means of their peregrinations across the globe, the people affected constituting merely hosts for a vast cycle of viral reproduction: one could say that it is not so much a matter of people catching viruses as viruses passing through people ${ }^{4}$. Finally, the account arrives at the confrontation between China and the WHO, or rather between Geneva and Beijing, which remains the most spectacular and, without a doubt, historically the most important aspect of the SARS crisis. In this grand history, Greenfeld highlights the role of an individual, Jiang Yanyong, whose letter published by Time Asia provoked a turnaround in the policy of the Chinese government. Greenfeld analyses the reasons that pushed this respected military surgeon to become a whistle blower ${ }^{5}$. It was not so much the humiliations of the Cultural Revolution as the memory of the Tiananmen massacre that came to Jiang Yanyong's mind as he received patients in respiratory distress and saw Zhang Wenkang announce on television that Beijing had the disease under control. However, there is little information on what subsequently happened to the imprudent doctor, who after a short period of glory in the Chinese press was detained for criticising the "Tiananmen incident." Likewise, Green feld enlarges little upon the political changes that resulted from Jiang Yanyong's revelation, notably the reshuffle provoked by $\mathrm{Hu}$ Jintao and Wen Jiabao when they realised that the SARS crisis provided an opportunity to distance themselves from the politics of Jiang Zemin.

6 On the effectiveness of the Chinese recovery of control, which coincided, in fact, with the end of the epidemic, Greenfeld has few hypotheses. The account is more informative on the possibility of locking up the Chinese information system than on the 
manner in which these incidents were recovered by this system - in this sense, Jiang Yanyong's act offers even more material for analysing the relationship between the media and politics in China. There is also little information on the way in which the WHO was able to organise its strategy faced with the Chinese government: even if Greenfeld openly admits that, at a time when the United States was invading Iraq in contempt of the UN, the restored authority of the WHO had something comforting about it (p. 138), he has trouble hiding the biased assumption that an international organisation is necessarily manipulated by the state powers it endeavours to regulate. We thus do not know, by the end of the work, how China 's mobilisation against SARS was able to coordinate with that of the WHO following a period of open opposition. All of the complex interaction between the Chinese government and the local elite escapes Greenfeld, who remains attached to a fixed, monolithic, and ultimately very negative image of China : during a trip to Shanxi, where he interviews the health authorities on the SARS cases in the countryside, he describes the dirtiness of the roads and houses and concludes, "All these people, they're just meat for virus."

7 The anti-Chinese prejudice that becomes increasingly perceptible as the book progresses is apparent from the very title of the work: the "China syndrome" is SARS, or rather the inability of China to mobilise in time against SARS; and the "21st Century's First Great Epidemic" is the one that appeared in southern China , presaging other pandemics to come - avian flu or others. If Greenfeld gives a high profile to the discovery of Guan Yi, according to which the SARS virus emerged in the animal markets of Guangzhou and Shenzhen, that is because it reinforces the image of a China ready to explode, a veritable virus bomb mixing people and animals in an inextricable confusion, the "Ground Zero" of bio-terrorist attacks to come (p. 342). From this point of view, the attraction of the book is that it imbues virology, a technical and precise discipline, with a genuine fascination for those who worry about the threats hanging over their lives: it is the destiny of our organisms that is being played out in China , a veritable breeding ground for the viruses that will kill us tomorrow. This lesson of the book hides another so subtle that the author has been prevented from formulating it: Hong Kong , thanks to its colonial past and its scientific equipment, is a real sentinel for observing and controlling diseases that are emerging not only in China but throughout the rest of Southeast Asia . It has to be remembered that when the WHO experts gave the new disease the name of severe acute respiratory syndrome, observers immediately made a connection between the acronym SARS and the status of Special Administrative Region (SAR) bestowed upon Hong Kong when it reverted to Chinese sovereignty in 1997. SARS is without doubt less the "China syndrome" than the "Hong Kong disease" in the sense that it revealed to the world the structural strengths and weaknesses of Hong Kong, and contributed powerfully to giving it a new identity in the context of the "one country, two systems" concept. Greenfeld relates, moreover, that he himself was one of the 500,000 people who marched in the streets of Hong Kong on 1 July 2003 in protest against Article 23 of the Basic Law, but even more profoundly, against a government that was not adequately protecting them against the threats they perceived confronting them from the mainland.

8 Thomas Abraham's book provides a corrective to the partiality and subjectivity of Greenfeld's account. The historical and scientific hindsight Abraham applies to the same events cast doubts on the validity of several of Greenfeld's statements. The work deals with China before discussing Hong Kong, and this order radically alters the presentation of the problem. Abraham recalls that Guangzhou doctors had identified 
the disease in December 2003 and prepared emergency plans indicating how to recognise and treat patients suffering from "atypical pneumonia." He analyses in fine detail the media coverage of the first cases and the subtle semantics through which the authorities simultaneously acknowledged and denied the rumour. He also provides important information on China 's strategy against SARS, in par- ticular the construction in one week of a thousand- bed hospital intended for patients presenting the symptoms of the disease. He discusses the debate surrounding the quarantine measures at Amoy Garden, and recreates with great precision the epidemiological investigation led by Thomas Tsang that enabled the ventilation system to be identified as the source of the contagion. He shows that Hong Kong took up the fight against SARS two weeks late because of the city's focus on avian flu, and he reproduces the controversies surrounding the efficacy of the measures taken at the Prince of Wales Hospital and the Department of Health. He underlines the vigour of the WHO directors, in particular Gro Harlem Brundtland (whom Greenfeld surprisingly does not mention) and David Heymann, who broke with precedent to criticise the Chinese government for its lack of co-operation. He also shows the reticence of the Center for Disease Control in Atlanta to follow the WHO recommendations, and its ultimate alignment with other countries in the global question of the crisis. It is in the last chapter, entitled "The virus hunt," that Abraham finally describes with great clarity and precision the discoveries by the team of Malik Peiris and Guan Yi concerning the coronavirus and its animal origins. Thomas Abraham in fact attended numerous conferences and work meetings of the microbiologists at the University of Hong Kong, where he teaches, and this experience has given him first-hand knowledge of the scientific data he discusses although he also tends, because of this, to play down the research conducted at the Chinese University of Hong Kong, in particularly on the efficacy of traditional Chinese medicine in the treatment of SARS 6

9 The great advantage of Thomas Abraham's book is above all to place SARS in the context of other infectious diseases that have made headlines in the past 20 years Aids, Ebola, Nipah, Marburg - by providing factors for interpreting the pre-eminence it has been accorded. If it is essentially the metaphor of war that has been applied to SARS, Abraham shows that this metaphor is justified in the case of viruses whose distinctive feature is to violently occupy the host cells in order to reproduce (the paradox being that the virus ends up destroying the cell that enabled it to live), but he also underlines that SARS was perceived as a global war from the start, as it spread by the most rapid means of transport and affected all categories of the population indiscriminately. The analogy with terrorist attacks springs immediately to mind - it is striking that the room occupied by the "super-spreader" Liu Jianlun at the Metropole Hotel was No. 911, for the virus literally transforms an ordinary person into a living bomb - and numerous Japanese manga cartoons have exploited the visual possibilities of this metamorphosis. In this war of man against virus, nurses become the soldiers dying at the front line without having been prepared for such attacks, valorised as secular martyrs in the same manner as New York's firefighters. In unfurling this string of metaphors, Thomas Abraham does not apply the scepticism of the semiologist, and he thus gives an effective account of the global mobilisation against this disease and the lessons that have been drawn from it for the prevention of similar diseases. "SARS has attracted the attention that it has because it affected the more globalised cities and regions of the world: China, Hong Kong, Singapore, Taiwan, Toronto . In the same way, the avian flu pandemic has taken on such an importance because the richest and 
the most powerful nations of the world are as vulnerable to this disease as the poorest." (Preface)

\section{NOTES}

1. See D. Fidler SARS, Governance and the Globalization of Disease, Basingstoke , Palgrave Macmillan, 2004, for an approach that clearly favours the WHO, and A. Kleinmann and J. Watson (eds.), SARS in China, Prelude to Pandemics, Stanford University Press, 2006, for an approach more favourable to China. The reviews of these works by A. Guilloux in Perspectives chinoises (nos. 92 and 99) underline the overly general characterisation of "China" and "world organisation" as entities.

2. See the review of this book by A. Danchin, founder of the Pasteur Research Centre at the University of Hong Kong , in La Recherche, 2006, no. 401, p. 89

3. On these cases, see P.C. Leung and E.E. Oi (eds.) SARS war, Combating the disease, World Scientific Publishing Co, Singapore, 2003 (for Toronto and Taiwan ), and C. M. Hoong, A Defining Moment. How Singapore beat SARS, Singapore, Stamford Press, 2004.

4. In this sense, this book unconsciously illustrates the method inaugurated by Bruno Latour in Les microbes : guerre et paix, Paris , Métailié, 1984 (translated into English under the title The Pastorization of France, Harvard University Press, 1988).

5. See on this point $\mathrm{F}$. Chateauraynaud and $\mathrm{D}$. Torny, Les sombres précurseurs, Une sociologie pragmatique de l'alerte et du risque, Paris, EHESS, 1999.

6. On this point, see P. C. Leung, "Efficacy of Chinese Medicine for SARS," in P. Tambyah and P. C. Leung (eds.), Bird Flu. A Rising Pandemic in Asia and Beyond, World Scientific Publishing Co, Singapore, 2006, p. 147-166. 